\title{
New Diagnostic and Therapeutic Aspects of Bipolar Disorders
}

\author{
3rd Symposium of the Munich and Freiburg Stanley Medical Research \\ Institute (SMRI) Center
}

Of course, it cannot be called a tradition yet. But it has now been the third year in a row, where specialists interested in bipolar disorder met for this up-to-date exchange on research. And, for the first time, it became an international event. Supported by a grant from GlaxoSmithKline, it was possible to bring together European scientists and clinicians actively involved in bipolar research. Thus, the topics of the 3rd Symposium on Bipolar Disorder of the Stanley Foundation Centers Munich and Freiburg, which took place in Andechs November 3, 2001, do not only reflect the research landscape in Germany, but also include hot topics from Spain and the UK. Similar to the proceedings of the 1st symposium in Munich 1999 and the 2nd symposium in Freiburg 2000, outstanding presentations and posters were chosen by the scientific committee and compiled for this supplement of Neuropsychobiology, in order to also have those participate who had not been able to come to Andechs.

In 2002, this annual meeting will pause as we have the exciting event of the 3rd European Stanley Conference on Bipolar Disorder in Freiburg, organized by our center. We look forward to the 4th meeting of the Munich-Freiburg SMRI center in 2004, and hope that, meanwhile, the reader will enjoy this special supplement of Neuropsychobiology.

H. Grunze

J. Walden

\footnotetext{
KARGER

Fax + 41613061234 E-Mail karger@karger.ch www.karger.com

(C) 2002 S. Karger AG, Basel

0302-282X/02/0465-0001\$18.50/0

Accessible online at: www. karger.com/nps
} 